\title{
THE PROBLEM OF AN ANTIDIURETIC SUBSTANCE IN THE BLOOD OF PATIENTS WITH ECLAMPSIA AND OTHER HYPERTENSIVE DISEASES
}

\author{
WITH OBSERVATIONS ON SPINAL FLUID
}

\author{
By GEORGE LEVITT \\ (From the Lasker Foundation for Medical Research and the Department of Medicine, \\ University of Chicago, Chicago)
}

(Received for publication September 23, 1935)

In 1931 Anselmino and Hoffmann (1) reported that they found in the ultrafiltrates of blood from 24 cases of " nephritic-eclamptic" patients a substance which they identified as the pressor-antidiuretic secretion of the posterior lobe of the hypophysis. Their patients had systolic blood pressures above $180 \mathrm{~mm} . \mathrm{Hg}$ and were edematous. When $10 \mathrm{cc}$. of the blood ultrafiltrate from these patients were injected subcutaneously into rabbits, it inhibited water diuresis. When injected intravenously into rabbits it raised the blood pressure. The active substance was destroyed by alkali. They prepared their blood ultrafiltrates by adding $1 \mathrm{cc}$. of normal acetic acid to each $20 \mathrm{cc}$. of citrated plasma. The mixture was then filtered through an aceto-collodion filter until two-thirds of the original volume had passed through. Immediately before injection into rabbits, the ultrafiltrate was neutralized with $\mathrm{NaOH}$. The acetic acid was added to bring the plasma to a $\mathrm{pH}$ of about 4.0. This $\mathrm{pH}$ was stated to be the optimum one for separation of the hormone from plasma proteins.

Since we began our work, de Wesselow and Griffiths (2), Byrom and Wilson (3), Theobald (4), and Hurwitz and Bullock (5) have reported adversely on the findings of Anselmino and Hoffmann. Theobald devotes much of his excellent paper to a review and criticism of the works of Anselmino and Hoffmann. In this report one may find a thorough discussion of the technical stages and their interpretations.

In the present work an attempt was made to demonstrate only the antidiuretic hormone of the posterior lobe of the hypophysis.

\section{METHOD}

Adult male rabbits weighing between 3.8 and $5 \mathrm{kgm}$. were used. Five rabbits were used throughout these experiments. They were chosen on the basis of rather constant diuresis under standard conditions and of uniform antidiuretic response to "pitressin." 1 The weight of the rabbits bore no relation to the amount of "pitressin" needed to inhibit diuresis. This had been noted by Theobald (4) in dogs. The animals were fed daily on oats, a liberal amount of fresh lettuce, and fresh tap water. The lettuce was fed five hours before the experiment to insure adequate tissue hydration. The time of this feeding was most important; otherwise the diuretic curves were not constant. The animal was tied on its back during the entire experiment. It was given $125 \mathrm{cc}$. of tepid tap water by stomach tube, and a Number 8 soft rubber catheter was inserted into the bladder and left in place. Care was taken to avoid irritation of the bladder; otherwise the urine output was irregular. The bladder was gently expressed at the beginning of the experiment, and every 30 minutes thereafter. The volume of urine and chloride concentration (Volhard-Harvey method (8)) were determined on each specimen. The average diuretic response to $125 \mathrm{cc}$. of water by stomach tube was determined in control experiments on alternate days for a period of 4 weeks.

The normal response was quite constant, as is shown in Figures 1, 2, and 3. (In these and the succeeding charts, the points on the curve represent the amount of urine collected during the preceding half hour, and the concentration of chloride in that urine in milligrams per cent of $\mathrm{NaCl}$.) Figure 1 is an average curve for 20 determinations on 5 rabbits. Figures 2 and 3 show four

\footnotetext{
1 Parke, Davis and Company-standardized to 20 pressor units per cc. This brand of "pitressin" was used in all experiments.
} 

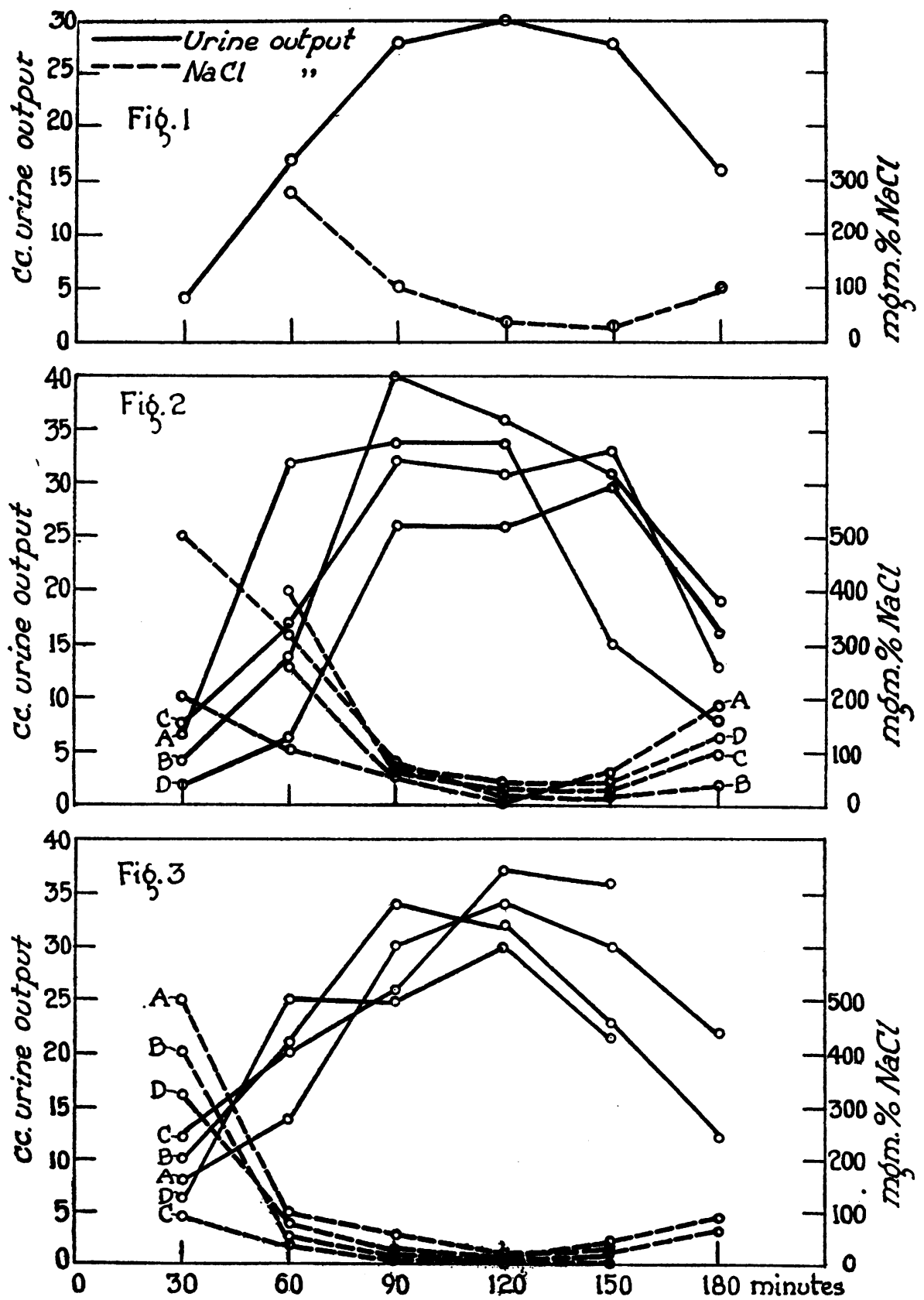

Fig. 1. Average Normal Output, 20 Determinations, 4 Separate Experiments, on EACH of 5 RabBits.

In these as in all experiments shown in these figures, $125 \mathrm{cc}$. tepid tap water were given by stomach tube at $O$.

Fig. 2. Normal Output, Rabbit 2, 4 Alternate Days.

Fig. 3. Normal Output, Rabbit 7, 4 Alternate Days. 
consecutive curves on alternate days, on two rabbits.

\section{RESULTS}

The experiments can be placed under four headings: 1-the determination of the minimal amounts of pitressin necessary to cause a definite antidiuresis and increase the $\mathrm{NaCl}$ concentration (measured as chlorides) when injected subcutaneously in $10 \mathrm{cc}$. of 0.900 saline; 2 -the study of the effects of subcutaneous injections of $10 \mathrm{cc}$. of human spinal fluid; 3-the investigation of methods of recovering the antidiuretic hormone from blood, both in vivo and in vitro; 4-attempts to find the antidiuretic substance in the blood of hypertensive, pre-eclamptic, and eclamptic patients.

1. Minimal amount of pitressin needed to inhibit water diuresis. The rabbits were prepared as described previously. Ninety minutes after the water was given by stomach tube, if the volume of urine was $25 \mathrm{cc}$. or over in the third half hour, varying amounts of pitressin were given in $10 \mathrm{cc}$. of saline subcutaneously. Subcutaneous rather than intravenous administration was chosen in order to make these experiments analogous to the experiments with ultrafiltrates. The latter contained 2.8 per cent $\mathrm{NaCl}$ which alone could have pronounced effects on diuresis if the ultrafiltrate were given intravenously. It was found that 0.002 unit of pitressin per animal caused a maximum inhibiting effect. Larger doses merely prolonged the action, and still further raised the chloride concentration. For example, with doses as large as 0.2 unit, the $\mathrm{NaCl}$ concentration rose to 3 per cent. It was found that the minimal amount of pitressin which caused a definite and constant decrease in the urine output and increased the chloride concentration was 0.00002 unit. An average curve for 20 such experiments is shown in Figure 4. Figure 5 shows such a single curve for each of the five animals.

2. The antidiuretic effect of human spinal fluid. Spinal fluid was chosen because it is in some respects a natural ultrafiltrate. Hoyle (6) has recently reviewed this subject and attempted to find the hormone of the posterior lobe in the spinal fluid of hypertensives. His methods did not include an antidiuretic test. Employing the uterine strip, melanophore expanding, and blood pressure determinations, Hoyle was able only in isolated instances to find small amounts of the pressor-oxytocic principle.

We obtained cerebrospinal fluid from 25 patients on the neurologic service; in 4 instances it was secured by cisternal puncture and in 21 by lumbar puncture after the first $40 \mathrm{cc}$. had been discarded. This would insure the use of fluid directly from the cisterna. The patients from whom spinal fluids were drained were a heterogeneous group, including none with either hypertension or pituitary disease. Ten cc. of the fluid were injected subcutaneously into rabbits. The urine volumes and chloride concentrations were not affected by any of the cerebrospinal or cisternal fluids.

3. Methods of separating the antidiuretic substance from the blood. The method used by Anselmino and Hoffmann was followed with one exception-namely, our filtering bags were made of a 10 per cent nitrocellulose solution in equal parts of 95 per cent alcohol and ethyl ether. The bags were filled and suspended in an empty flask to which suction was applied by a water pump. Pitressin in normal saline could be recovered by this treatment in direct proportion to the volume filtered. It was found necessary to add at least 2 units of pitressin to $50 \mathrm{cc}$. of dog blood in order to obtain an ultrafiltrate that would give a response in rabbits comparable to the effect of 0.00002 unit of pitressin. Pitressin was also injected intravenously into dogs, and the blood withdrawn from the femoral artery 2 to 3 minutes after injection. It was necessary to give 8 units to dogs weighing 12 to 14 kilos to get an antidiuretic effect on rabbits from the ultrafiltrate of $50 \mathrm{cc}$. of the dog blood.

Since it was inconceivable that such huge amounts of posterior pituitary hormone could be circulating in any free form, other means of separating the "pitressin" from the blood were tried. The following method gave the best results, although it confirmed the suspicion that most of the pitressin must be bound in the blood, and could not be recovered in the ultrafiltrate. Blood in $50 \mathrm{cc}$. amounts was drawn into a syringe containing $2 \mathrm{cc}$. of 5 per cent sodium citrate and $0.5 \mathrm{cc}$. of normal $\mathrm{HCl}$, and centrifuged. To each $10 \mathrm{cc}$. of plasma was slowly added enough concentrated $\mathrm{HCl}$ to bring the $\mathrm{pH}$ near 1.0 (about 

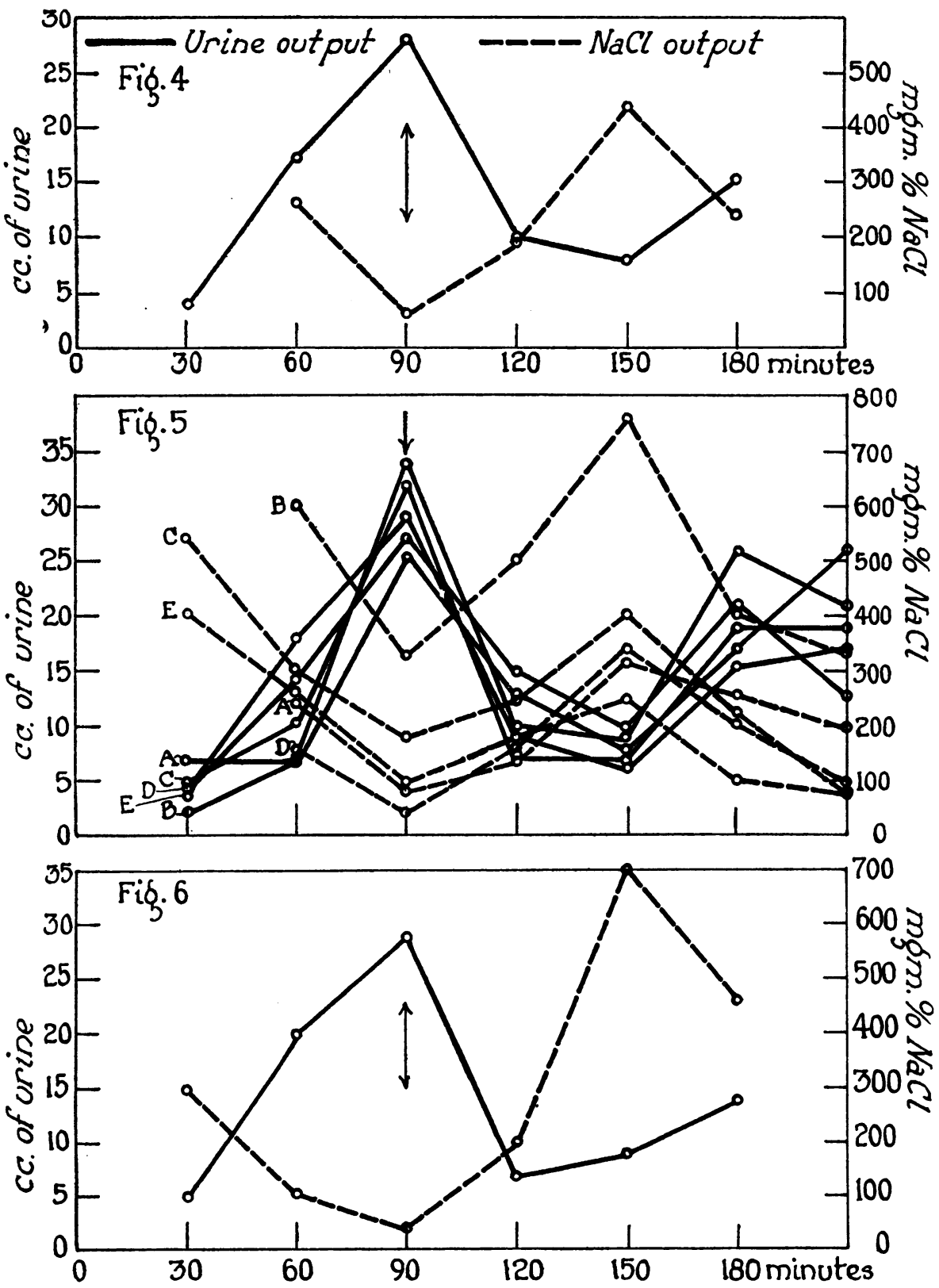

Fig. 4. 0.00002 Unit of Pitressin in 10 cc. Normal Saline Subcutaneously. Average Curve, 20 Determinations, 4 Separate Experiments on Each of 5 Rabbits.

In this as in all succeeding figures, arrow indicates time at which injection was given.

Fig. 5. 0.00002 Unit of Pitressin in 10 cc. Normal Saline Subcutaneously. 1 Curve on Each of 5 RabBits.

Fig. 6. $10 \mathrm{cc}$. Ultrafiltrate Subcutaneously Injected into Rabbit 12.

(Ultrafiltrate was prepared from blood withdrawn from femoral artery of a dog weighing 12 kilos three minutes after intravenous injection of 1 unit of pitressin.) 
$0.3 \mathrm{cc}$. was required). Thymol blue was used as an indicator. The mixture was brought to boiling, quickly cooled, and centrifuged. Because small amounts of protein were still suspended in the supernatant fluid, the latter was filtered through a Berkefeld filter, fitted over with a nitrocellulose alcohol-ether bag. A water pump supplied the suction. Twenty cubic centimeters could be ultrafiltered in $1 \frac{1}{2}$ to 2 hours. The solution was neutralized with 10 per cent $\mathrm{NaOH}$ (Brom thymol blue) immediately before subcutaneous injection into rabbits. It had a $\mathrm{NaCl}$ content of 2.8 per cent.

As a control, this entire procedure was applied to $10 \mathrm{cc}$. of saline containing 0.00002 unit of pitressin. As measured in rabbits, its antidiuretic effect and ability to raise the concentration of urinary chlorides was not impaired. With this method, an effect comparable to that of 0.00002 unit of pitressin could be obtained by adding 0.1 unit of pitressin to $50 \mathrm{cc}$. of dog blood, or by injecting 1 unit of pitressin intravenously into dogs weighing 12 and 14 kilos (Figure 6). In other words, 8 to 10 times as much of the added or injected pitressin could be removed from blood as by the previous method. After injecting pitressin into a dog, it was found that the greatest amount was present within 2 to 3 minutes after injection. Even after the intravenous injection of 15 units, with the animal showing severe general effects, no pitressin could be recovered if the blood was withdrawn 12 minutes or longer after the injection. It is obvious that under favorable circumstances less than 0.01 per cent of pitressin added to blood in vitro was ultrafilterable.

4. Attempts to find antidiuretic substance in the blood of hypertensive, pre-eclamptic, and eclamptic patients. The bloods were all treated by the $\mathrm{HCl}$ method just described. Fifty cubic centimeters of blood were used. In the first group are 25 patients, 14 males and 11 females, with essential hypertension or hypertensive glomerulonephritis, all with diastolic pressures over $120 \mathrm{~mm}$. of mercury. The resulting diuretic curves in the test rabbits were all normal.

In the second group are 15 patients diagnosed as pre-eclamptic. These were patients who, during their pregnancy, began to run an elevated blood pressure (150 to $200 \mathrm{~mm}$. $\mathrm{Hg}$ systolic), and to show moderate amounts of albumin in the urine. A few had early mild edema of the face and extremities. The ultrafiltrate from their bloods produced no effects upon the diuretic curves in any way different from the control injection of $10 \mathrm{cc}$. amounts of saline (2.80 per cent).

In the third group are four cases of severe eclampsia. These patients showed generalized edema, extensive albuminuria, diastolic pressures over $130 \mathrm{~mm}$. of mercury, systolic pressures over $200 \mathrm{~mm}$., convulsions, and coma. The blood was withdrawn before treatment was begun. The ultrafiltrate from all 4 cases produced a slight and transient antidiuretic effect, unaccompanied by any significant change in the chloride concentration of the urine. The record from 3 of these experiments is shown in Figures 7, 8, and 9.

\section{DISCUSSION}

It is obvious that the methods hitherto described are entirely inadequate to remove from the blood the antidiuretic factor of the posterior lobe of the hypophysis. It has been shown that such small amounts of commercial pitressin as 0.00002 unit can produce a definite inhibition of water diuresis in rabbits, as well as raising the chloride concentration. If only this amount can be found in the ultrafiltrate from $50 \mathrm{cc}$. of blood to which 0.1 unit has been added, it would seem that excessive amounts of the posterior pituitary hormone might be circulating in the blood and escape detection by the present methods. The interpretation of the curves from the severe eclamptic cases is difficult. The type of curve was constant for the 4 cases of severe eclampsia. Here we see slight inhibition of water diuresis without change in the urinary chlorides. There may be many causes for this, one of which is suggested in Figure 10. This typical curve resulting from sub-minimal doses of pitressin (0.000002 unit) in rabbits shows a slight and short inhibiting effect on the urine output, without changing the chloride concentration. It is only when larger amounts of pitressin are used that the chloride concentration in the urine rises. The antidiuretic effect, as noted in our curves for severe eclamptics, may be due also to a liver substance. Theobald suggested this possibility because of the work of Theobald and White(7). For the present, there is no good 

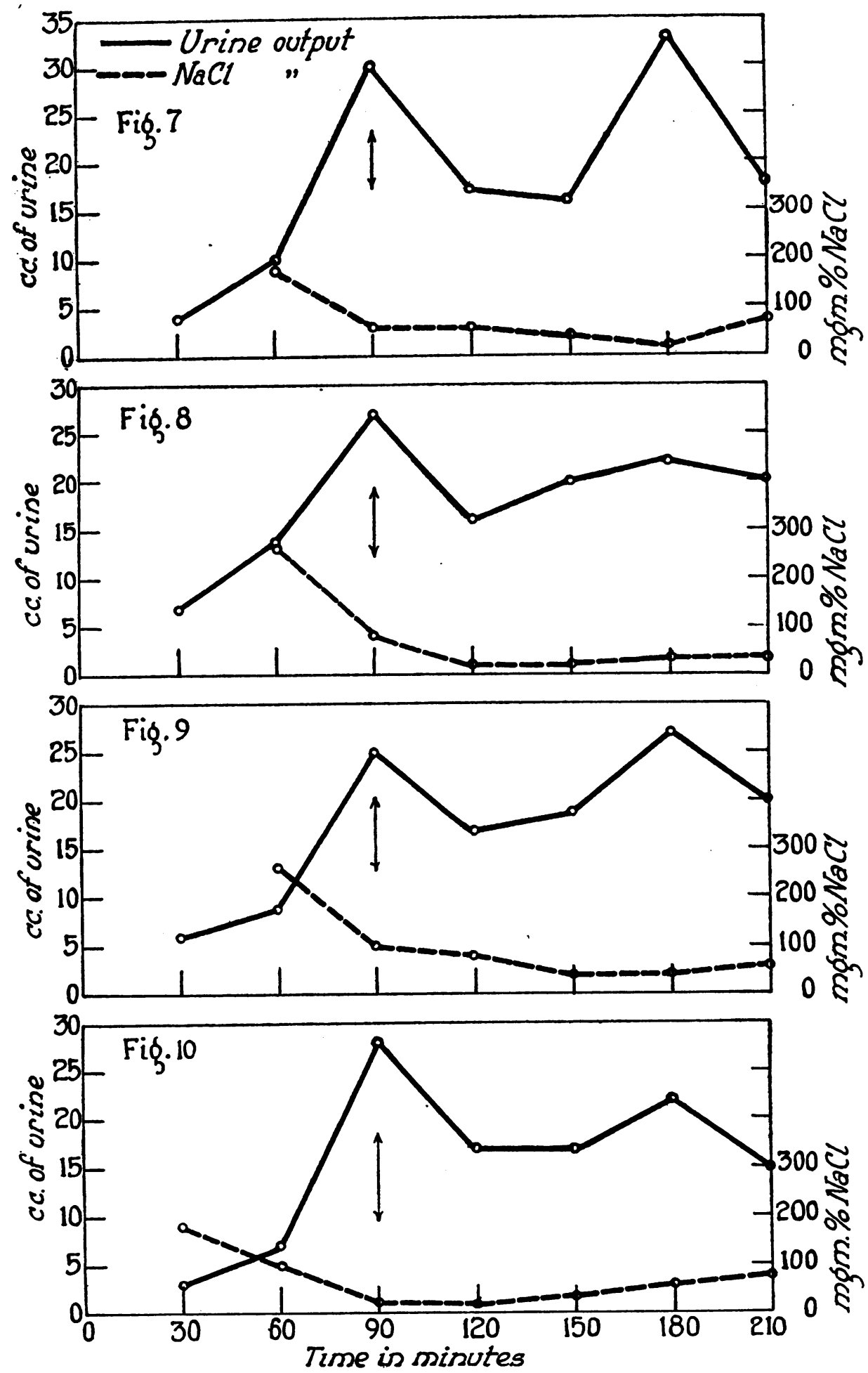

Fig. 7. 10 cc. Ultrafiltrate of Blood from Eclamptic Patient M. G. Injected Subcutaneously into RabBit 12.

Fig. 8. 10 cc. Ultrafiltrate of Blood from Eclamptic Patient E. W. Injected INTO RABBIT 13.

Fig. 9. 10 cc. Ultrafiltrate of Blood from Eclamptic Patient M. M. Injected INTO RABBIT 2.

Fig. 10. Subcutaneous Injection of 0.000002 Unit Pitressin into Rabbit 13. 
evidence that hyperfunction of the posterior lobe of the hypophysis is an important factor in eclampsia. An increase in the posterior pituitary hormone could not account, so far as we know, for the high blood pressures. Experimental administration of effective doses of the hormone to women in the latter third of pregnancy might help to settle the problem.

\section{CONCLUSIONS}

1. In rabbits weighing from 4 to 5 kilos, the subcutaneous injection of 0.00002 unit of pitressin definitely and constantly inhibits water diuresis and increases the chloride concentration of the urine. Maximum antidiuresis results from 0.002 unit per rabbit.

2. Sub-minimal doses of pitressin $(0.000002$ unit) may have a slight inhibiting effect on water diuresis without significantly affecting the chloride concentration of the urine.

3. After injection of pitressin intravenously into dogs, the antidiuretic factor could be isolated from the dog's arterial blood only within the first 12 minutes following injection.

4. The ultrafiltrate of blood to which pitressin has been added contains only approximately 0.01 per cent of the original pitressin. Therefore all but a small fraction of the hormone is held by the non-filterable portion of the blood.

5. The cerebrospinal fluids of non-hypertensive patients and the ultrafiltrates from bloods of hypertensives and pre-eclamptic patients had no effect on water diuresis when injected into rabbits.

6. In 4 severe cases of eclampsia the blood ultrafiltrates caused a slight inhibition of water diuresis without altering the concentration of urinary chlorides.
7. If the blood of patients with eclampsia and related disturbances does contain an increased amount of the hormone from the posterior lobe of the hypophysis, our present methods are unable to detect it.

The author wishes to acknowledge gratefully the assistance and interest of Dr. Louis Leiter, under whose direction this work was carried out.

\section{BIBLIOGRAPHY}

1. Anselmino, K. J., and Hoffmann, F., Die Ubereinstimmungen in den klinischen Symptomen der Nephropathie und Eklampsie der Schwangeren mit den Wirkungen des Hypophysenhinterlappenhormons. Arch. f. Gynäk., 1931, 147, 597.

Vermehrung des Hypophysenhinterlappenhormons im Blute und Art und Schwere der klinischen Erscheinungen bei der Nephropathie und Eklampsie der Schwangeren. Arch. f. Gynäk., 1931, 147, 621.

2. de Wesselow, O. L. V. S., and Griffiths, W. J., On the question of pressor bodies in the blood of hypertensive subjects. Brit. J. Exper. Path., 1934, 15, 45.

3. Byrom, F. B., and Wilson, C., The alleged pituitary origin of the eclamptic and pre-eclamptic toxemias of pregnancy. Quart. J. Med., 1934, 3, 361.

4. Theobald, G. W., The alleged relation of hyperfunction of the posterior lobe of the hypophysis to eclampsia and the nephropathy of pregnancy. Clin. Sc., 1934, 1, 225.

5. Hurwitz, D., and Bullock, L. T., Failure to find pressor and antidiuretic substances in patients with toxemia of pregnancy. Am. J. M. Sc., 1935, 189, 613.

6. Hoyle, C., Pituitary secretion in high blood pressure. Quart. J. Med., 1933, 2, 549.

7. Theobald, G. W., and White, M., An antidiuretic substance extracted from the liver. J. Physiol. (Proc.), 1933, 78, 18.

8. Peters, J. P., and Van Slyke, D. D., Quantitative Clinical Chemistry. II. Methods. Williams and Wilkins Co., Baltimore, 1932, p. 833. 